African Journal of Biotechnology Vol. 11(7), pp. 1705-1718, 24 January, 2012

Available online at http://www.academicjournals.org/AJB

DOI: $10.5897 / A J B 11.2046$

ISSN 1684-5315 @ 2012 Academic Journals

Full Length Research Paper

\title{
Cloning and expression of a Trichoderma longibrachiatum $\beta$-mannanase gene in Pichia pastoris
}

\author{
J. L. Lim ${ }^{1,2}$, F. D. A. Bakar ${ }^{1}$, H. M. Yusof ${ }^{2}$ and A. M. A. Murad ${ }^{1 *}$ \\ ${ }^{1}$ School of Biosciences and Biotechnology, Faculty of Science and Technology, Universiti Kebangsaan \\ Malaysia, 43600 Bangi, Selangor, Malaysia. \\ ${ }^{2}$ Sime Darby Technology Centre, 1st Floor Block B, UPM-MTDC III, Lebuh Silikon 43400, \\ Serdang, Selangor, Malaysia. \\ Accepted 11 November, 2011
}

\begin{abstract}
Trichoderma species are among the primary producers of $\beta$-mannanase, an enzyme that catalyses the

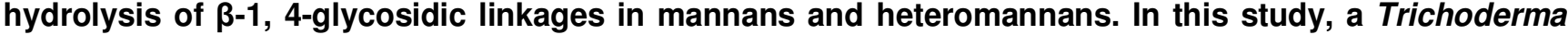
species producing high mannanase activity was identified as Trichoderma longibrachiatum based on sequence analysis of its rDNA internal transcribed spacer region. The open reading frame of the gene encoding for $\beta$-mannanase of $T$. longibrachiatum, man1 is $1,441 \mathrm{bp}$ and is separated by two introns. The MAN1 amino acid sequence showed $95 \%$ identity to Trichoderma reesei $\beta$-mannanase. Domain analysis classified MAN1 as a member of glycosyl hydrolase family 5 and detected the presence of a carbohydrate-binding domain family 1 at its C-terminus. The recombinant mannanase, rMAN1, was successfully expressed as a $\sim 60 \mathrm{kDa}$ extracellular recombinant protein in Pichia pastoris and was verified via western blotting analyses. The specific activity of the purified rMAN1 was $1416.18 \mathrm{U} / \mathrm{mg}$. The optimal rMAN1 activity was recorded at $55^{\circ} \mathrm{C}$ and $\mathrm{pH} 5$. The enzyme was stable with 30 min preincubation at temperatures ranging from 4 to $50^{\circ} \mathrm{C}$. The enzyme was stable at pH 4 to 7 but became progressively unstable at pH values below 3 and above 8. rMAN1 had a high affinity towards locust bean gum as a substrate, with a $\mathrm{K}_{\mathrm{m}}$ value of $0.95 \mathrm{mg} / \mathrm{ml}$.
\end{abstract}

Key words: Trichoderma longibrachiatum, mannanase, Pichia pastoris, expression, recombinant.

\section{INTRODUCTION}

$\beta$-Mannan-based polysaccharides including linear mannans, glucomannans, galactomannans and galactoglucomannans are a major component of the hemicellulose fraction in higher plant cell walls (Petkowicz et al., 2001). The degradation of the mannan backbone depends on the action of $\beta$-mannanases (EC

\footnotetext{
${ }^{*}$ Corresponding author. E-mail: munir@ukm.my or munir8488@gmail.com. Tel: +6-03-89215696. Fax: +60389252698 .
}

3.2.1.78), $\beta$-mannosidases (EC 3.2.1.25) and $\beta$ glucosidases (EC 3.2.1.21). $\beta$-Mannanases are endohydrolases that catalyze the random hydrolysis of $\beta$ 1,4-linkages within the main chain of mannans (McCleary, 1988). The $\beta$-mannanase sequence analyzes the assigned members of this enzyme to either glycosyl hydrolase $(\mathrm{GH})$ family 5 or 26 . However, the mannanases in family 26 are of bacterial origin with the exception of a few anaerobic fungi. Both bacterial and eukaryotic mannanases have been annotated to family 5 .

Mannanases have drawn scientific and commercial attention because of their possible application in pulp 
Table 1. Oligonucleotide primers used in the study.

\begin{tabular}{lll}
\hline Primer & DNA sequence (5' to 3') & Function \\
\hline ITS1 (F) & TCCGTAGGTGAACCTGCGG & To amplify the ITS region with a size between 600 to 800 bp \\
ITS4 (R) & TCCTCCGCTTATTGATATGC & \\
1 F & GGCTACTTYGCSGGWWCSAAC & To amplify the partial man1 gene with a size of $~ 450$ bp \\
$1 \mathrm{R}$ & CARCTCCCACGCAAABAYSGC & \\
TSP 1 & TATCCCGCCGTAGTCGTT & To amplify the upstream sequence of the partial man1 gene \\
TSP 2 & GCTCAGCGGACTTGACTACAT & \\
TSP 3 & TTGACATCGTTGAAGCCCATAC & \\
TSP 4 & ACCTTCAGCCACATCGCCT & To amplify the downstream sequence of the partial man1 gene \\
TSP 5 & GAACGACTACGGCGGGATAAA & \\
TSP 6 & CACCTGGTTCACTAACTCGGCG & \\
man1F & GGCTTACACCTTTGCATGAT & To amplify the man1 cDNA with a size of 1.3 kb \\
man1R & GTGTCGTCTCCCTCTTTCTCAAT & \\
PK-F & GGTACCGCCTCAAGCTTTGTGACAA & To amplify the man1 cDNA for cloning into expression vector \\
PX-R & TCTAGACCTGCAGACAGGCACTGCG & \\
\hline
\end{tabular}

(Montiel et al., 1999), coffee (Sachslehner et al., 2000), detergent (Aehle, 2007) and poultry feeds (Mehri et al., 2010) industries. Given the natural abundance of mannan, a wide variety of bacteria, actinomycetes, yeasts and fungi are known to be mannan degraders (Montiel et al., 1999; Puchart et al., 2004; Mudau and Setati, 2008; Bo et al., 2009). Mannanases are also produced in higher plants such as tomato (Marraccini et al., 2001) and are present in the gut of invertebrates such as the marine mollusk Mytilus edulis (Xu et al., 2002). Among the sources of mannanase, the production of $\beta$-mannanase by microorganisms is the most promising due to its low cost, high production rate and readily manipulated conditions. In practice, microorganisms utilized in producing mannanases are primarily fungi belonging to the genera Aspergillus (Chen et al., 2006), Sclerotium (Sachslehner et al., 2000) and Trichoderma (Ferreira and Filho, 2004).

In this work, a mannanase encoding gene from a fungus that produces mannanase with relatively high activity was isolated. The mannanase gene was cloned and expressed in $P$. pastoris, a methylotrophic yeast known for producing foreign proteins at high levels, providing proper protein folding and growing to high cell densities using inexpensive media. Subsequently, the enzyme was purified, and its biochemical properties were characterized.

\section{MATERIALS AND METHODS}

\section{Strains and plasmids}

Trichoderma sp. strain DSM 63060 was obtained from the German
Collection of Microorganisms and Cell Cultures (DSMZ), Germany. The Escherichia coli strain DH5a was obtained from the Molecular Mycology Laboratory, Universiti Kebangsaan Malaysia, Malaysia, and the $P$. pastoris strain X-33 was purchased from Invitrogen, USA. pGEM- $T^{\circledR}$ Easy Vector was purchased from Promega, USA, and the pPICZ $\alpha A$ vector was obtained from Invitrogen, USA. The pGEM-T ${ }^{\circledR}$ Easy Vector was used for DNA cloning procedures, whereas pPICZaA was used for the heterologous expression of recombinant $\beta$-mannanase. The pPICZ $\alpha A$ vector contains DNA sequences coding for an $\alpha$-factor signal peptide at the $\mathrm{N}$-terminus and a histidine tag (with six His residue) at the $\mathrm{C}$-terminus.

\section{Cloning of rDNA internal transcribed spacer (ITS)}

Trichoderma sp. DSM 63060 was grown in potato dextrose yeast extract broth (10 peptone, 10 yeast extract and $4 \mathrm{~g} / \mathrm{L}$ dextrose) at $30^{\circ} \mathrm{C}$ and $180 \mathrm{rpm}$ on a rotary shaker. After 3 days of incubation, the mycelia were harvested in sterile conditions and grounded for genomic DNA extraction using polyvinylpyrrolidone (PVP) as described by Oh et al. (2009). The amplification of the ITS region from Trichoderma sp. DSM 63060 genomic DNA was carried out using universal fungal primers ITS1 and ITS4 (Table 1) (White et al., 1990). The PCR conditions were as follows: $94^{\circ} \mathrm{C}$ for $3 \mathrm{~min}$, followed by 30 cycles at $94^{\circ} \mathrm{C}$ for $30 \mathrm{~s}, 62^{\circ} \mathrm{C}$ for $30 \mathrm{~s}, 72^{\circ} \mathrm{C}$ for $1 \mathrm{~min}$ and $72^{\circ} \mathrm{C}$ for $7 \mathrm{~min}$. The PCR products were purified and cloned into pGEM-T ${ }^{\circledR}$ Easy Vector to facilitate DNA sequencing.

\section{Isolation of the man1 gene}

The degenerate primers $1 \mathrm{~F}$ and $1 \mathrm{R}$ (Table 1 ), used to amplify a partial $\beta$-mannanase gene, man1, from Trichoderma sp. DSM 63060 genomic DNA, were designed based on the conserved amino acid sequences of $\beta$-mannanase from $T$. reesei (accession no. AAA34208), Aspergillus sulphureus (accession no. ABC59553) and Aspergillus aculeatus (accession no. AAA67426) aligned using ClustalW version 2.0 (http://www.ebi.ac.uk/Tools/clustalw/; Larkin et 
al., 2007). The amplification was carried out by an initial denaturation at $94^{\circ} \mathrm{C}$ for $3 \mathrm{~min}, 30$ cycles at $94^{\circ} \mathrm{C}$ for $30 \mathrm{~s}$, annealing temperatures for $30 \mathrm{~s}$, and $72^{\circ} \mathrm{C}$ for $1 \mathrm{~min}$, with the final extension cycle at $72^{\circ} \mathrm{C}$ for $7 \mathrm{~min}$. The $\mathrm{PCR}$ products were subjected to DNA sequencing, and the sequences were analyzed using BLAST version 2.2.22 (http://blast.ncbi.nlm.nih.gov/; Altschul et al., 1997) to identify and confirm the identity of the amplified fragment. Based on the DNA sequences, three pairs of targetspecific primers (TSP 1-6, Table 1) were designed for DNA walking PCR to isolate the remaining man1 DNA sequence. DNA walking PCR was conducted using the DNA walking SpeedUp ${ }^{T M}$ premix kit II (Seegen Inc., Korea) following the manufacturer's instructions. All PCR products were purified and sequenced.

\section{Cloning of the man1 cDNA}

Trichoderma sp. DSM 63060 were grown in $0.5 \%(\mathrm{w} / \mathrm{v})$ locust bean gum (LBG) broth (Sigma-Aldrich, USA) for 4 days at $30^{\circ} \mathrm{C}$ and 180 rpm. The mycelia were harvested using several pieces of muslin cloth and subjected to total RNA extraction using TRIzol ${ }^{\circledR}$ reagent (Invitrogen, USA) following the manufacturer's instructions.

The first-strand CDNA of man1 was synthesized using the Omniscript ${ }^{\circledR}$ reverse transcription kit (Qiagen, USA) according to the manufacturer's instructions. The man 1 cDNA was amplified using total RNA as template and specific primer pair man1F/man1R (Table 1). The PCR conditions were as follows: $94^{\circ} \mathrm{C}$ for $3 \mathrm{~min}, 30$ cycles at $94^{\circ} \mathrm{C}$ for $30 \mathrm{~s}, 60^{\circ} \mathrm{C}$ for $30 \mathrm{~s}, 72^{\circ} \mathrm{C}$ for $100 \mathrm{~s}$ and $72^{\circ} \mathrm{C}$ for 7 min. The purified PCR products were ligated into pGEM-T ${ }^{\circledR}$ Easy Vector to generate plasmid pGEMT-man.

\section{Nucleotide and amino acids sequence analysis}

Sequence analysis of the ITS region was performed using TrichOKEY version 2 (http://www.isth.info/tools/molkey/index.php; Druzhinina et al., 2005). This program was developed for the identification of Hypocrea/Trichoderma species. The putative motifs in the promoter region were predicted using the Neural Network Promoter Prediction version 2.2 (http://www.fruitfly.org/seq_tools/promoter.html; Reese, 2001). The SignalP server version 3.0 (http://www.cbs.dtu.dk/services/SignalP/; Bendtsen et al., 2004) and Phobius version 1.0 (http://phobius.sbc.su.se/; Käll et al., 2004) were used to predict the signal peptide of MAN1. ClustalW software (htpp://www.ch.embnet.org/software/ClustalW.html; Larkin et al., 2007) and BOXSHADE software (http://www.ch.embnet.org/ software/BOX_form.html) were utilized to compare the MAN1 sequence with other fungal mannanases available in the public database. The MAN1 domain structure was examined using the Pfam database (http://pfam.sanger.ac.uk/search; Finn et al., 2008).

\section{Construction of the expression plasmid}

The man1 cDNA was amplified using the primer pair PK-F and PX$\mathrm{R}$ (Table 1). The PK-F primer was constructed such that it introduced a Kpnl restriction site at the $\mathrm{N}$-terminus, whereas the PX-R primer was designed to add an Xbal restriction site with two additional nucleotides at the $\mathrm{C}$-terminus so that the reading frame through the $\mathrm{C}$-terminal (His) 6 tag was preserved. The amplification was performed using plasmid pGEMT-man as a template with the following conditions: $94^{\circ} \mathrm{C}$ for $3 \mathrm{~min}, 30$ cycles at $94^{\circ} \mathrm{C}$ for $30 \mathrm{~s}$, $60^{\circ} \mathrm{C}$ for $30 \mathrm{~s}, 72^{\circ} \mathrm{C}$ for $100 \mathrm{~s}$ and $72^{\circ} \mathrm{C}$ for $7 \mathrm{~min}$. A PCR product with the size of $\sim 1.3 \mathrm{~kb}$ was ligated into the pGEM-T $T^{\circledR}$ Easy Vector to generate pGEMT-man1. This plasmid was digested by Kpnl and $X b a l$, and the $\sim 1.3 \mathrm{~kb}$ digestion product was ligated into the $\mathrm{pPICZ} \alpha \mathrm{A}$ vector to generate plasmid $\mathrm{pPICZ} \alpha \mathrm{A}-\mathrm{man} 1$.

\section{Recombinant protein expression}

The plasmid pPICZaA-man1w was linearized using Sacl and electroporated into $P$. pastoris $\mathrm{X}-33$ competent cells to generate clone X-33/MAN1. A positive transformant was selected on YPD (1.0 yeast extract, 2.0 peptone, 2.0 dextrose and 2.0\% agar) plates supplemented with $2000 \mu \mathrm{g} / \mathrm{ml} Z_{\text {Zeocin }}{ }^{\mathrm{TM}}$. As a control, P. pastoris $\mathrm{X}-33$ was transformed with $\mathrm{pPICZ} \alpha \mathrm{A}$ vector without a DNA insert; the clone was designated as X-33/pPICZaA. Selected zeocinresistant colonies were grown in Buffered glycerol-complex medium (BMGY: 1\% yeast extract, 2\% peptone, $100 \mathrm{mM}$ potassium phosphate at $\mathrm{pH} 6,1.34 \%$ yeast nitrogen base, $0.4 \mu \mathrm{g} / \mathrm{ml}$ biotin, $1 \%$ glycerol) containing $1 \%$ casamino acid overnight at $30^{\circ} \mathrm{C}$ and 250 rpm (Al-Rashed et al., 2010). The cells were harvested by centrifugation in a swing-out rotor at $4000 \mathrm{rpm}$ (5415R centrifuge, Eppendorf, Germany) for $10 \mathrm{~min}$ at room temperature and thoroughly re-suspended in expression media, Buffered methanolcomplex media (BMMY: contains $0.5 \%$ methanol instead of glycerol in BMGY), to an absorbance of $\sim 1.0$ at $600 \mathrm{~nm}$. The culture was further grown at $30^{\circ} \mathrm{C}$ with shaking at $250 \mathrm{rpm}$. Sterile methanol was supplemented into the expression media to a final concentration of $0.5 \%$ every $24 \mathrm{~h}$. The cultures were drawn at day 1 2,3 and 4 to detect the expression of the recombinant mannanase (rMAN1). Moreover, the expression levels were analyzed at different methanol induction concentrations ranging from 0.1 to $3.0 \%$. Subsequently, the proteins in each culture supernatant were concentrated via ultrafiltration using the Vivaspin $20 \mathrm{ml}$ centrifugal concentrator with a $10 \mathrm{kDa}$ molecular weight cut-off (Sartorius Stedim Biotech, Germany). Recombinant proteins in the concentrated filtrates were detected by western blot, and the expression levels were assessed via SDS-PAGE and assayed for $\beta$-mannanase activity.

\section{Western blotting}

Separated proteins in the $12 \%$ resolving gel (Laemmli, 1970) were transferred to a nitrocellulose membrane using the Mini Trans-blot system (Bio-Rad Laboratories Inc., USA) and run at $200 \mathrm{~mA}$ for $2 \mathrm{~h}$. After transfer, the membrane was probed sequentially with a $1 / 5000$ $(\mathrm{v} / \mathrm{v})$ dilution of mouse anti-His-tag $\operatorname{lgG}$ antibody (Novagen, Germany) and 1/10000 (v/v) dilution of horseradish peroxidaseconjugated goat anti-mouse secondary antibody (Invitrogen, USA). The reaction was visualized using the SuperSignal West Pico Chemiluminescent substrate kit (Pierce, USA).

DNS assay for the measurement of recombinant $\beta$-mannanase activity

$\beta$-Mannanase activity was determined by monitoring the amount of reducing sugars liberated by the recombinant enzymes acting on galactomannan, such as LBG. The assay mixture for $\beta$-mannanase activity consisted of $0.625 \%(\mathrm{w} / \mathrm{v}) \mathrm{LBG}$ dissolved in $0.8 \mathrm{ml}$ of $50 \mathrm{mM}$ 
citrate sodium buffer at $\mathrm{pH} 5$ and $0.2 \mathrm{ml}$ of appropriately cell-free culture supernatant. After the mixture was incubated at $55^{\circ} \mathrm{C}$ for 5 min, the reaction was stopped by the addition of $1 \mathrm{ml}$ of 3 , 5dinitrosalicylic acid, as described by Miller (1959). The reaction was boiled for $10 \mathrm{~min}$ and cooled to room temperature before the $A_{540}$ was measured. The activity can be calculated based on the $A_{540}$ value, where one unit of $\beta$-mannanase activity is defined as the amount of enzyme required to produce one $\mu \mathrm{mol}$ of reducing sugar per min.

\section{Recombinant protein purification}

The $5 \mathrm{ml} \mathrm{His} \mathrm{trap} \mathrm{column} \mathrm{was} \mathrm{equilibrated} \mathrm{with} \mathrm{binding} \mathrm{buffer} \mathrm{(20}$ $\mathrm{mM} \mathrm{NaH} \mathrm{PO}_{4}, 0.5 \mathrm{M} \mathrm{NaCl}, \mathrm{pH}$ 7.4) until the UV absorbance established a stable baseline. The concentrated culture supernatant was loaded into a $5 \mathrm{ml}$ His trap column at a flow rate of $1 \mathrm{ml} / \mathrm{min}$. The column was washed with $50 \mathrm{ml}$ of binding buffer at a flow rate of $1 \mathrm{ml} / \mathrm{min}$ to remove the unbound proteins, and the bound protein was eluted with $50 \mathrm{ml}$ of elution buffer $\left(20 \mathrm{mM} \mathrm{NaH}_{2} \mathrm{PO}_{4}, 0.5 \mathrm{M}\right.$ $\mathrm{NaCl}, 200 \mathrm{mM}$ imidazole, $\mathrm{pH}$ 7.4) at the same flow rate. Both unbound and bound proteins were analyzed with SDS-PAGE and western blotting.

\section{Effect of temperature and $\mathrm{pH}$ on enzymatic activity}

The optimal temperature for rMAN1 activity was determined by incubating $0.3 \mu \mathrm{g}$ of purified enzyme with $0.5 \%$ LBG dissolved in 50 $\mathrm{mM}$ sodium citrate buffer at temperatures ranging from 4 to $90^{\circ} \mathrm{C}$ for $5 \mathrm{~min}$. To estimate the thermal stability, $0.3 \mu \mathrm{g}$ of purified enzyme was pre-incubated in $100 \mu \mathrm{l}$ of $50 \mathrm{mM}$ sodium citrate buffer $\mathrm{pH} 5$ at various temperatures ranging from 4 to $90^{\circ} \mathrm{C}$ for $30 \mathrm{~min}$. Subsequently, the rMAN1 activity was assayed under standard conditions $\left(\mathrm{pH} 5,55^{\circ} \mathrm{C}\right.$ for $\left.5 \mathrm{~min}\right)$. The optimum $\mathrm{pH}$ for rMAN1 activity was measured by incubating $0.3 \mu \mathrm{g}$ of purified enzyme with $0.5 \%$ LBG dissolved in the following $50 \mathrm{mM}$ buffers: glycine- $\mathrm{HCl}$ ( $\mathrm{pH} 2$ to 3), sodium citrate ( $\mathrm{pH} 3$ to 6$)$, sodium phosphate ( $\mathrm{pH} 6$ to 8 ) and Tris- $\mathrm{HCl}(\mathrm{pH} 8$ to 9$)$. The $\mathrm{pH}$ stability of the purified recombinant enzyme was determined by measuring the residual enzyme activity under standard conditions after incubation of $0.3 \mu \mathrm{g}$ of enzyme in the same buffer at $55^{\circ} \mathrm{C}$ for $30 \mathrm{~min}$.

\section{Substrate specificity and kinetic parameters}

Assays for $\beta$-mannanase activity were performed by incubating the $0.3 \mu \mathrm{g}$ of purified enzyme with LBG as well as guar gum at concentrations ranging from 0.5 to $2 \mathrm{mg} / \mathrm{ml}$ in $50 \mathrm{mM}$ sodium citrate buffer, $\mathrm{pH} 5$, at $55^{\circ} \mathrm{C}$ for $5 \mathrm{~min}$. The released oligosaccharides were measured by the DNS assay. The Michaelis-Menten constant $\left(\mathrm{K}_{\mathrm{m}}\right)$ and maximal velocity $\left(\mathrm{V}_{\max }\right)$ values were obtained from the Lineweaver-Burk plot.

\section{RESULTS AND DISCUSSION}

\section{Species identification}

The ITS DNA sequence data were collected, assembled and deposited into the NCBI nucleotide databases with the accession number HM192931. Sequence analysis of the ITS region using the TrichOKEY version 2 software showed that the isolated ITS DNA sequence belonged to T. longibrachiatum and Hypocrea orientalis. H. orientalis has been proposed as a teleomorph of $T$. longibrachiatum, and both are members of the Trichoderma section longibrachiatum (Samuels, 2006).

\section{Analysis of the nucleotide and deduced amino acid sequence of the $T$. longibrachiatum $\beta$-mannanase}

The full open reading frame of $T$. longibrachiatum $\beta$ mannanase gene, including DNA sequence $120 \mathrm{bp}$ upstream, is given in Figure 1. The presence of two introns in the $\beta$-mannanase coding sequence was evident by aligning genomic DNA with the cDNA sequence. Both introns were confirmed and contained the invariant sequence of GT at the 5' end and AG at the 3' end. Analysis of the partial promoter region identified a "TATA box-like" sequence (Breathnach and Chambon, 1981), 5'TATATAA-3', within the promoter at nucleotide -91 to -85 . An additional motif with the sequence 5'-GTCAAT-3', which was homologous to the "CAAT box" consensus sequence (Breathnach and Chambon, 1981), was found at nucleotide -104 to -99 . This DNA sequence was submitted to NCBI nucleotide databases with the accession number: HM230064. The gene was named man1 and contained a 1441-bp open reading frame encoding a 437 amino acid primary protein with a calculated molecular mass of $44.43 \mathrm{kDa}$.

The deduced amino acid sequence was subjected to signal peptide prediction. Analysis using both SignalP and Phobius software suggested that a putative signal peptide cleavage site was situated between Ala19 and 20, which appeared to be a typical signal peptidase I Ala-XAla processing site. Additionally, an eight amino acid putative propeptide was located after the cleavage site, and it may have been cleaved by a proline-directed arginyl protease (Schwartz, 1986). Four putative $\mathrm{N}$ glycosylation sites Asn-X-Ser/Thr, in which X represents any amino acids other than proline (Cereghino et al., 2002) were identified in MAN1.

T. longibrachiatum MAN1 showed 95, 58, 57 and 55\% identity to glycosyl hydrolase (GH) family $5 \beta$-mannanase of $T$. reesei MAN1, A. aculeatus MAN1, $A$. sulphureus MAN1 and $A$. fumigatus MANI, respectively. The high similarity of $\beta$-mannanase from $T$. longibrachiatum and $T$. reesei was due to the close relationship of the two species within the Trichoderma section longibrachiatum. In contrast, BLAST analysis revealed extremely weak similarities between the T. Iongibrachiatum MAN1 and the $\beta$-mannanases belonging to $\mathrm{GH}$ family 26 . Domain 


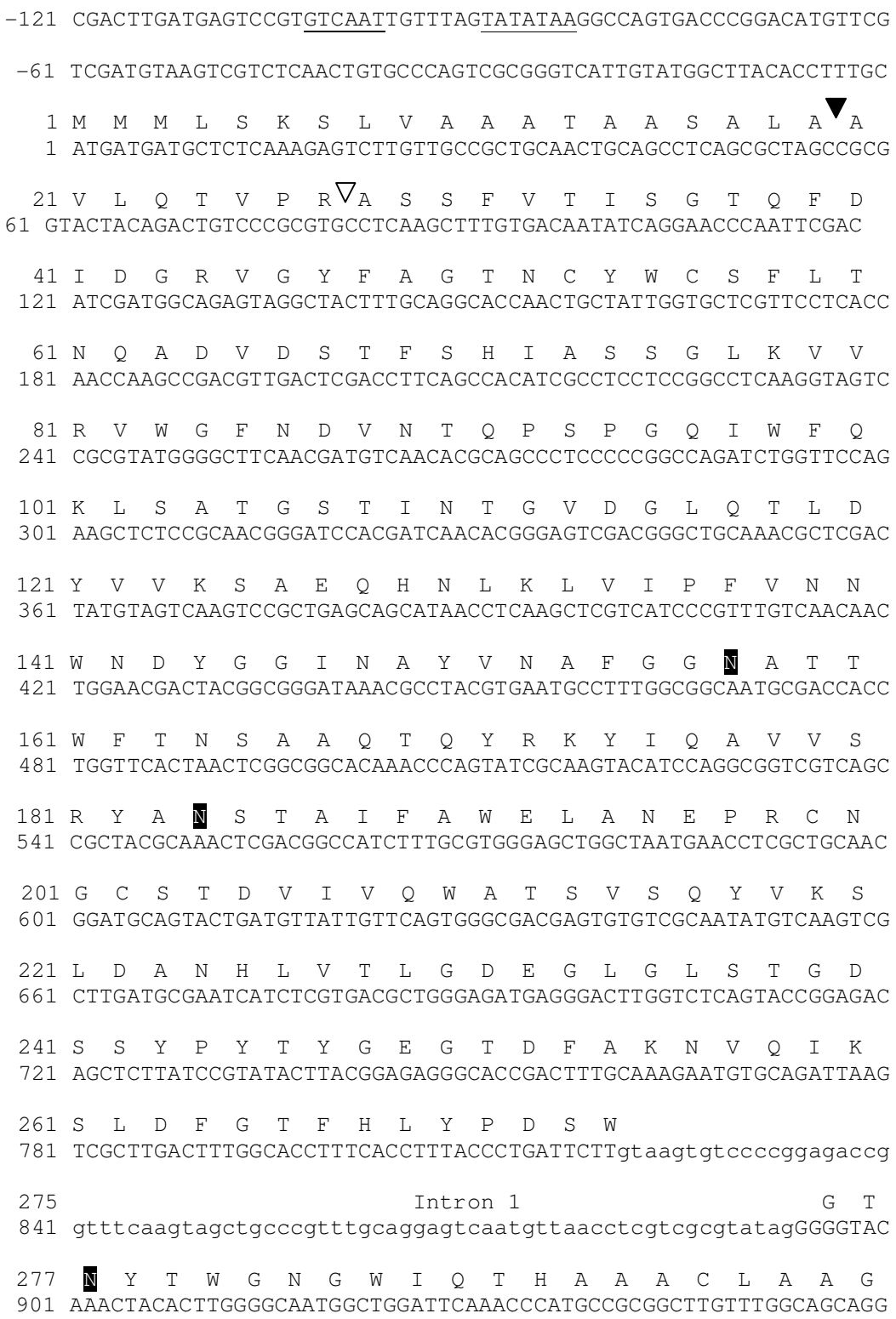

Figure 1. The nucleotide sequence of $T$. longibrachiatum man1 and the deduced amino acid sequence of MAN1. The DNA sequence is presented from the 5' to 3' end. The intron sequences are in lowercase. A CAAT box-like sequence is underlined with a single line, whereas a TATA box-like sequence is underlined with two lines. The standard one-letter amino acid code is also used. The presumed signal peptide and propeptide cleavage sites are indicated by a solid and open arrowhead, respectively. Potential $\mathrm{N}$-glycosylation sites are shaded in black. The stop codon is indicated by an asterisk $\left({ }^{*}\right)$.

analysis of MAN1 using Pfam database demonstrated that the protein structure at residues 14 to 279 had a high homology with that of $\mathrm{GH}$ family 5 catalytic domain. A carbohydrate-binding module of family 1 (CBM1) was also detected by Pfam at the $C$ terminus of MAN1. In addition to the two domains, two active sites, Glu169 and Glu276, were predicted on MAN1. In T. reesei MAN1, eight identified active site residues were Arg54, His102, Asn168, Glu169, His241, Tyr243, Glu276 and Trp306 (Sabini et al., 2000). These residues were also present in 


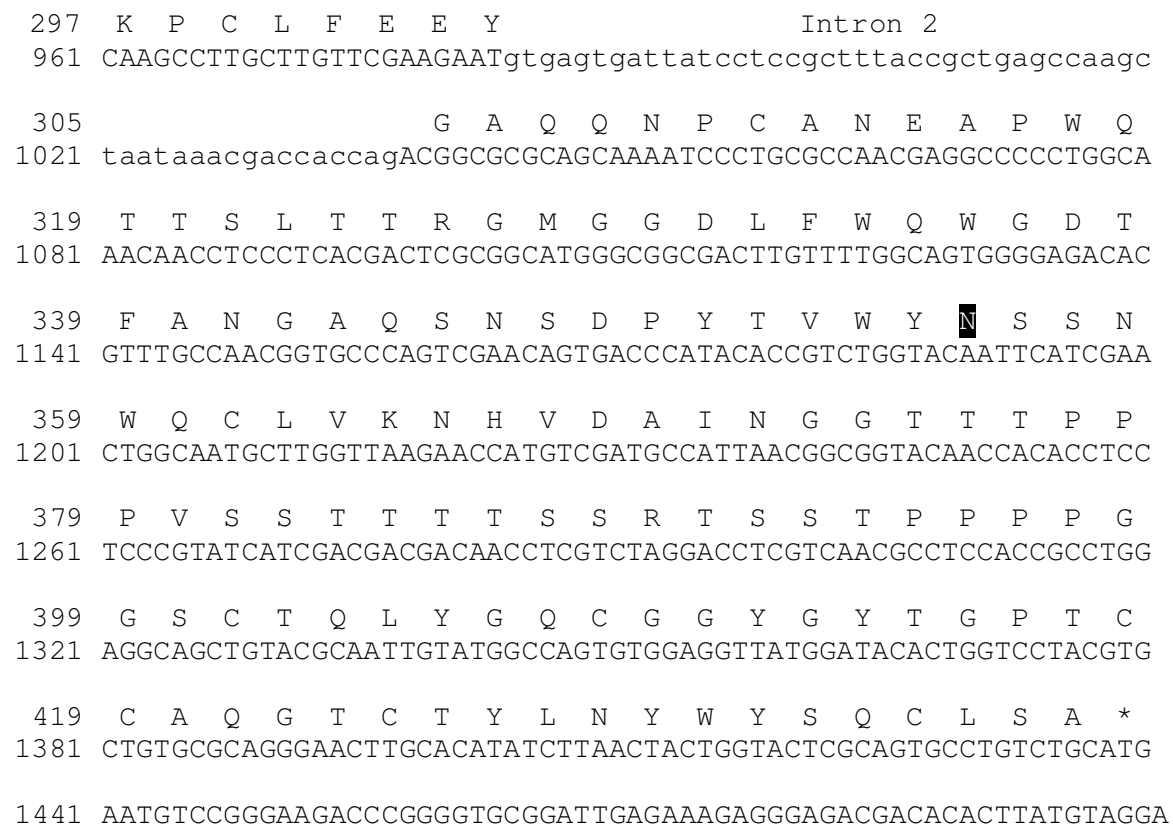

Figure 1: Continue

T. longibrachiatum MAN1 and conserved in several fungal mannanase (Figure 2), indicating the importance of these residues for the activity of the enzyme.

\section{Expression of $\beta$-mannanase in $\boldsymbol{P}$. pastoris}

SDS-PAGE showed that an intact band with a molecular weight of $\sim 60 \pm 5 \mathrm{kDa}$ was observed in culture filtrates of X-33/MAN1 with methanol induction (Figure 3a). As negative controls, culture filtrates of $P$. pastoris $\mathrm{X}-33$ and X-33/pPICZaA did not show any expressed protein or develop any signal via western blotting. Western blot analysis revealed that the protein was recognized specifically by anti-His IgG antibody, demonstrating that the expressed heterologous proteins were rMAN1 (Figure $3 b)$. The cell-free culture filtrates of X-33/MAN1 without methanol induction detected weak signals of MAN1 via western blotting. This result may be due to the basal expression of the protein in $P$. pastoris $\mathrm{X}-33$. As compared to the non-induction group, the presence of methanol was significantly important as it helped in the induction of rMAN1 production.

The rMAN1 activity of each clone was assayed using $0.5 \%$ LBG in $50 \mathrm{mM}$ citrate sodium buffer. These results show that the concentrated culture supernatant of $\mathrm{X}$ 33/MAN1 with methanol induction had higher activity $(343.56 \mathrm{U} / \mathrm{ml})$ than the control (Figure 4). However, culture filtrates of X-33/MAN1 without methanol induction had only slightly higher $\beta$-mannanase activity than the control ( $P$. pastoris $\mathrm{X}-33$ and $\mathrm{X}-33 / \mathrm{pPICZ} \alpha \mathrm{A})$, confirming the importance of methanol as an inducer of the strong AOX1 promoter.

\section{Determination of optimal post-induction time to harvest and methanol concentration for induction}

To examine the expression of rMAN1, the optimal conditions necessary for recombinant protein expression in $P$. pastoris were optimized. The first parameter investigated was to determine the optimal post-induction time to harvest rMAN1. The SDS-PAGE analysis showed that the protein band of rMAN1 was the most intense band in the sample that was induced for $48 \mathrm{~h}$ (Figure $5 \mathrm{a}$ ). This analysis was correlated with the result obtained for $\beta$ mannanase activity, because the highest $\beta$-mannanase activity was observed in concentrated culture supernatant that was harvested after $48 \mathrm{~h}$ of induction (Figure 5a). These results demonstrated that two days of induction were sufficient for the highest production of rMAN1. The decreased production of rMAN1 on day 3 and 4 may be due to cell death and it resulted in higher host proteases activity in the culture media (Zhang et al., 2007). The second parameter investigated was the optimal methanol concentration for induction.

The culture filtrates loaded onto SDS-PAGE $(30 \mu \mathrm{g})$ showed that the protein bands of rMAN1 were the most 
Trichoderma longibrachiatum

Aspergillus aculeatus

Aspergillus sulphureus

Aspergillus fumigatus

Trichoderma reesei

AQVGPWGQCGGRSYTGETSCVSGWSCVLFNEWYSQCQPATTTSTSSVSAT 50

Trichoderma longibrachiatum Aspergillus aculeatus

Aspergillus sulphureus

Aspergillus fumigatus

Trichoderma reesei

 -LPRTP-----NHNAATT----------AFPSTSGLHFTIDGKTGYFAGT 34 -LPKASPAPSTSSSSAST---------SFASTSGLQFTIDGETGYFAGT 39 AAPSST SSSKESVPSSTTSKKPVPTGSSSFVKADGLKFNIDGETKYFAGT 100

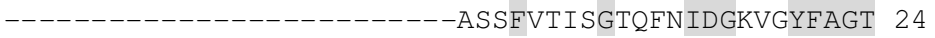

Trichoderma longibrachiatum NCYWCSFLTNQADVDSTFSHIASSGLKVVRVWGFNDVNTQPSPGQIWFQK 74 Aspergillus aculeatus Aspergillus sulphureus Aspergillus fumigatus NS YWIGF LTNNDDVDLVMSQLAASDLKILRVWGFNDVNTKPTDGTVWYQL 84 NSYWIGFLTDDSDVDLVMSHLKS SGLKILRVWGFNDVTTQPSSGTVWYQL 89 NAYWLPFLTNDADVDSVMDNLQKAGLKILRTWGFNDVNSKPSSGTVYFQL 150 Trichoderma reesei NCYWCSFLTNHADVDS TF SH ISS SGLKVVRVWGFNDVNTQP SPGQIWFQK 74

Trichoderma longibrachiatum LS--ATGSTINTGVDGLQTLDYVVKSAEQHNLKLVIPFVNNWNDYGGINA 122 Aspergillus aculeatus Aspergillus sulphureus Aspergillus fumigatus Trichoderma reesei HA--NGTSTINTGADGLQRLDYVVT SAEKYGVKL I INFVNEWTDYGGMQA 132 HQ--DGKSTINTGADGLQRLDYVVS SAEQHGIKLI INFVNYWTDYGGMSA 137 HDPS TGTTTINTGADGLQRLDYVVSAAEKRGIKLLIPLVNNWDDYGGMNA 200 LS--ATGSTINTGADGLQTLDYVVQSAEQHNLKLI IPFVNNWSDYGGINA 122

Trichoderma longibrachiatum Aspergillus aculeatus Aspergillus sulphureus Aspergillus fumigatus Trichoderma reesei

YVNAFGGN-ATTWFTNSAAQTQYRKYIQAVVSRYANSTAIFAWELANEPR 171 YVTAYGAAAQTDFYTNTAIQAAYKNYIKAVVSRYSSSAAIFAWELANEPR 182 YVSAYGGSDETDFYTSDTMQSAYQTYIKTVVERYSNSSAVFAWELANEPR 187 YVKAYGGS-KTEWYTNSQIPSVYQAYIKAVVSRYRDSLAIMAWELSNEAR 249 YVNAFGGN-ATTWYTNTAAQTQYRKYVQAVVSRYANSTAIFAWELGNEPR 171

Trichoderma longibrachiatum CNGCSTDVIVQWATSVSQYVKSLDANHLVTLGDEGLGLSTG-DSSYPYTY 220 Aspergillus aculeatus Aspergillus sulphureus CQGCDT SVLYNWISDTSKYIKSLDSKHLVTIGDEGFGLDVDSDGSYPYTY 232 CP SCDT TVLYDWIEKT SKF IKGLDADHMVCIGDEGFGLNTDSDGSYPYQF 237 CQGCSTDVIYNWAAKT SAYIKSLDPNHMVATGDEGMGVTVDSDGSYPYST 299 CNGCSTDVIVQWATSVSQYVKSLDSNHLVTLGDEGLGLSTG-DGAYPYTY 220

Trichoderma reesei

$\begin{array}{lll}\text { Trichoderma longibrachiatum } & \text { GEGTDFAKNVQIKSLDFGTFHLYPDSWGTNYT-WGNGWIQTHAAACLAAG } 269 \\ \text { Aspergillus aculeatus } & \text { GEGLNFTKNLGISTIDFGTLHLYPDSWGTSYD-WGNGWITAHAAACKAVG } 281\end{array}$ Aspergillus sulphureus AEGLNF TMNLGIDTIDFATLHLYPDSWGTSDD-WGNGWISAHGAACKAAG 286 YEGSDF AKNLAAPD IDFGVF HLYTEDWGIKDNSWGNGWVTSHAKVCKAAG 349 Aspergillus fumigatus GEGTDF AKNVQIKSLDFGTFHLYPDSWGTNYT-WGNGWIQTHAAACLAAG 269

Trichoderma reesei $\star *$

Trichoderma longibrachiatum Aspergillus aculeatus Aspergillus sulphureus Aspergillus fumigatus Trichoderma reesei

KPCLFE KPCLLE KPCLLE KPCLFE KPCVFE YGVTSNHCAVE SPWQQTA GNATGISGDLYWQYGTTESWGQSPN 331 YGVTSNHCSVESPWQQTALNTTGVSADLFWQYGDDLSTGESPD 336 YGLKDDHCSASPTWQKTSVSS-GMAADLFWQYGQTLSTGPSPN 398 YGAQQNPCTNEAPWQTTSLTTRGMGGDMFWQWGDTFANGAQSN 319

Trichoderma longibrachiatum Aspergillus aculeatus Aspergillus sulphureus Aspergillus fumigatus Trichoderma reesei

Trichoderma longibrachiatum Aspergillus aculeatus Aspergillus sulphureus Aspergillus fumigatus Trichoderma reesei
SDPYTVWYNSSNWQCLVKNHVDAINGGTTTPPPVSSTTTTSSRTSSTPPP 369 -DGNTFYYNTSDFTCLVTDHVAAINAQSK------------------- 359 -DGNTIYYGTSDYECLVTDHVAAIDSA-------------------- 362

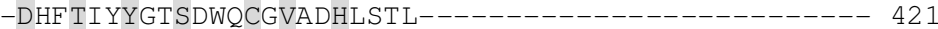
SDPYTVWYNSSNWQCLVKNHVDAINGGTTTPPPVSSTTTTSSRTSSTPPP 369

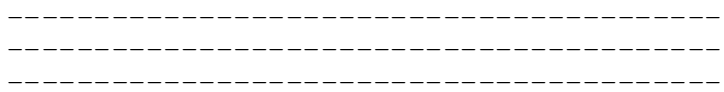

PGGSCSPLYGQCGGSGYTGPTCCAQGTCIYSNYWYSQCLNT 410

Figure 2. ClustalW alignment of $T$. longibrachiatum MAN1 with $\beta$-mannanases from T. reesei, A. aculeatus, $A$. sulphureus and $A$. fumigatus. Identical residues are indicated by a grey background, whereas putative catalytic residues are shown by a black background. Active site residues of $T$. reesei $\beta$-mannanase are indicated by an asterisk $\left(^{*}\right)$, whereas gaps in the sequence to facilitate the alignment are indicated by a hyphen(-). 
(a)

(b)
M
$\begin{array}{lllllll}M & 1 & 2 & 3 & 4 & 5 & 6\end{array}$
$\begin{array}{lllllll}M & 1 & 2 & 3 & 4 & 5 & 6\end{array}$

$\underset{58 \mathrm{kDa} \rightarrow-\infty}{80 \mathrm{kDa} \rightarrow+\infty}$

Figure 3. SDS-PAGE and western blot profiles of recombinant $\beta$-mannanase.(a) The SDS-PAGE (12\%) profile shows overexpression of recombinant mannanase at $~ 60 \mathrm{kDa}$. Lane M: Pre-stained protein marker (New England BioLabs ${ }^{\circledR}$, USA.); Lanes 1, 3 and 5: Proteins from culture filtrates of $P$. pastoris X-33, X-33/pPICZaA and X-33/MAN1W without methanol induction; Lanes 2, 4 and 6: Proteins from culture filtrates of $P$. pastoris X-33, X-33/pPICZaA and X-33/MAN1 with methanol induction. (b) Western blot analysis of SDS-PAGE from Figure $3 a$.

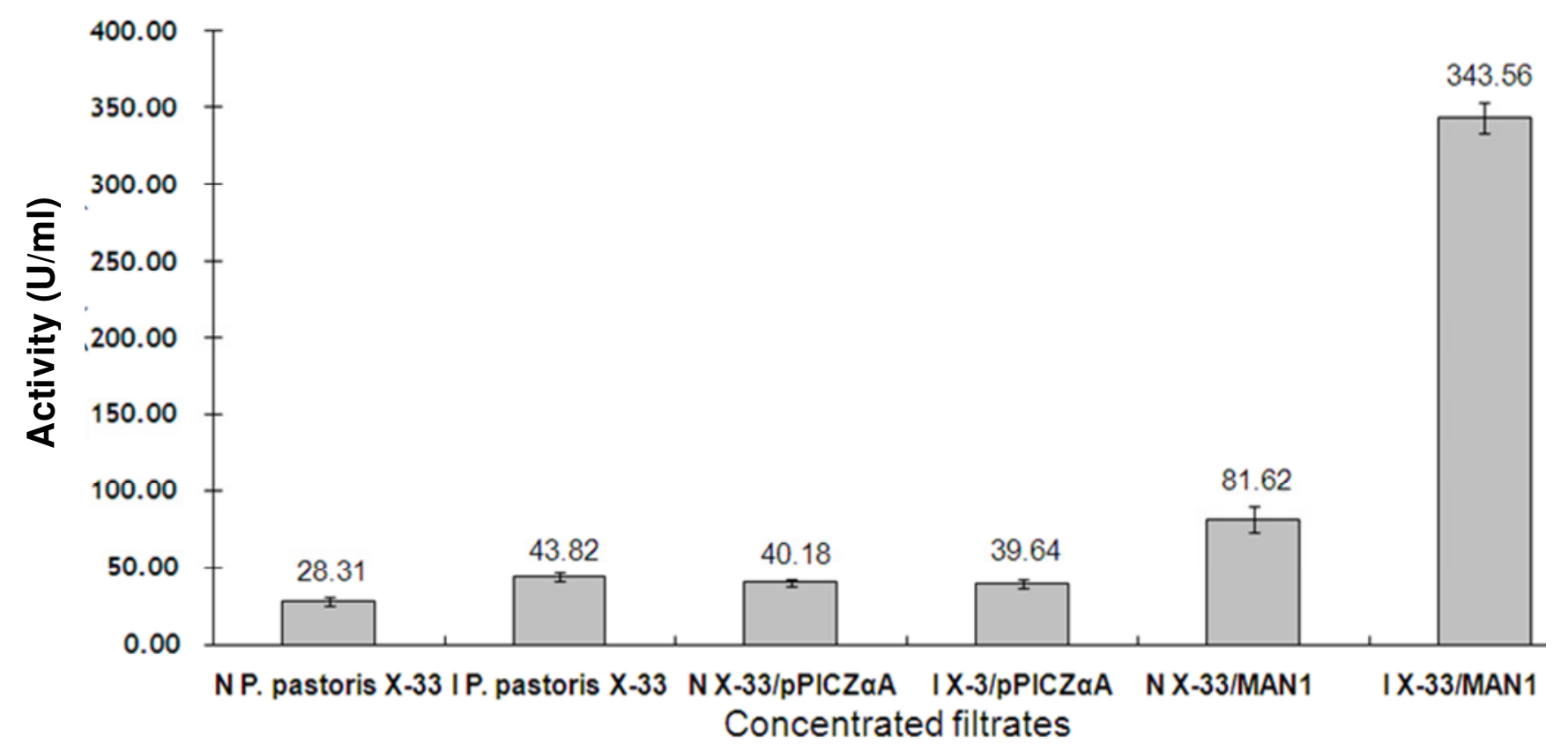

Figure 4. Comparison of enzymatic activity between partially purified proteins, which were grown with and without methanol, produced by $P$. pastoris X-33, X-33/pPICZaA and X-33/MAN1. The letter $\mathrm{N}$ in the graph represents non-induction, whereas the letter I represents induction. The standard deviations for triplicate samples are indicated with an error bar.

intense when X-33/MAN1 was induced with methanol at a final concentrations of $1.5 \%$ (Figure $5 b$ ). This observation is in agreement with the result obtained for the relative $\beta$-mannanase activity, and the highest activity was observed from the culture filtrates of X-33/MAN1 induced with $1.5 \%$ methanol (Figure $5 \mathrm{~b}$ ). 
(a)
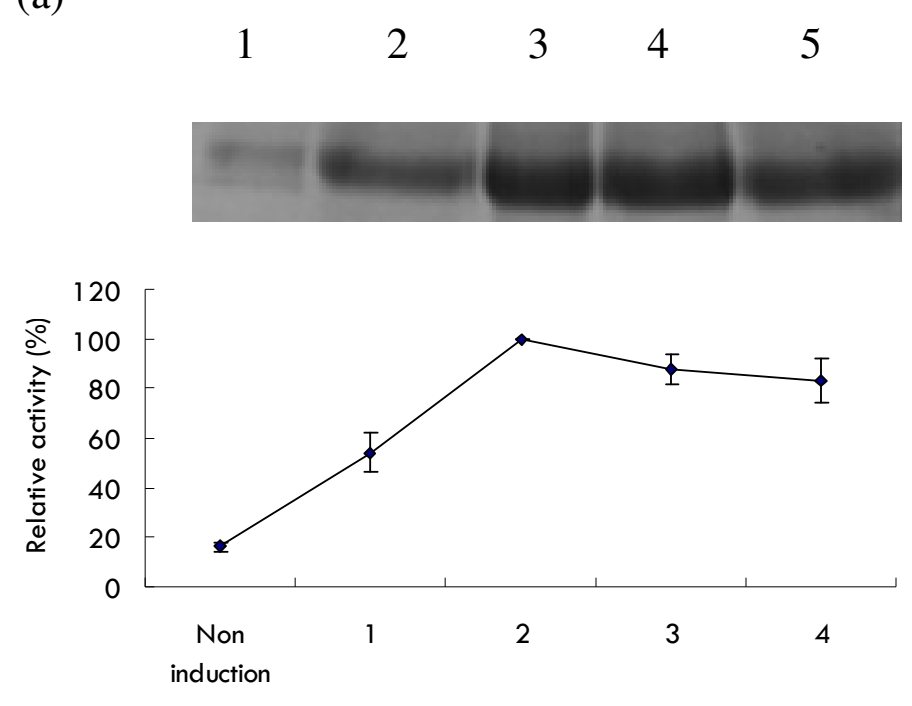

Day (b)

$\begin{array}{llllllll}1 & 2 & 3 & 4 & 5 & 6 & 7 & 8\end{array}$
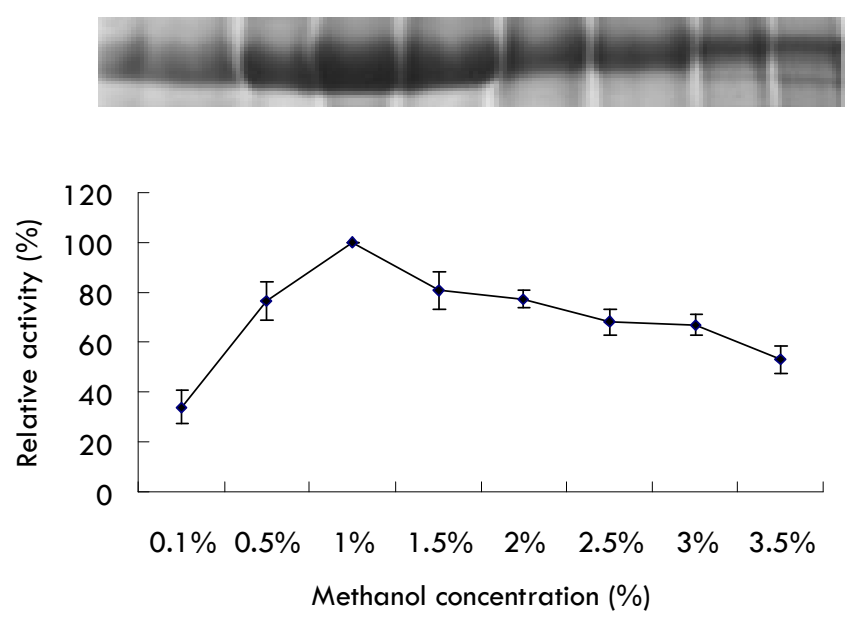

Figure 5. SDS-PAGE and relative recombinant $\beta$-mannanase activity profiles of culture filtrates harvested at different time points and concentrations of methanol. (a) Effect of induction times on MAN1 expression. Lane M: Pre-stained protein marker (New England BioLabs ${ }^{\circledR}$, USA); Lane 1: Protein produced by X-33/MAN1 with no methanol induction for 96 h; Lanes 2 to 5 : Proteins from X-33/MAN1 that were induced for 24, 48, 72 and $96 \mathrm{~h}$. (b) Effect of methanol concentration on MAN1 expression. Lanes 1 to 8: 0.1, $0.5,1,1.5,2,2.5,3,3.5 \%$.

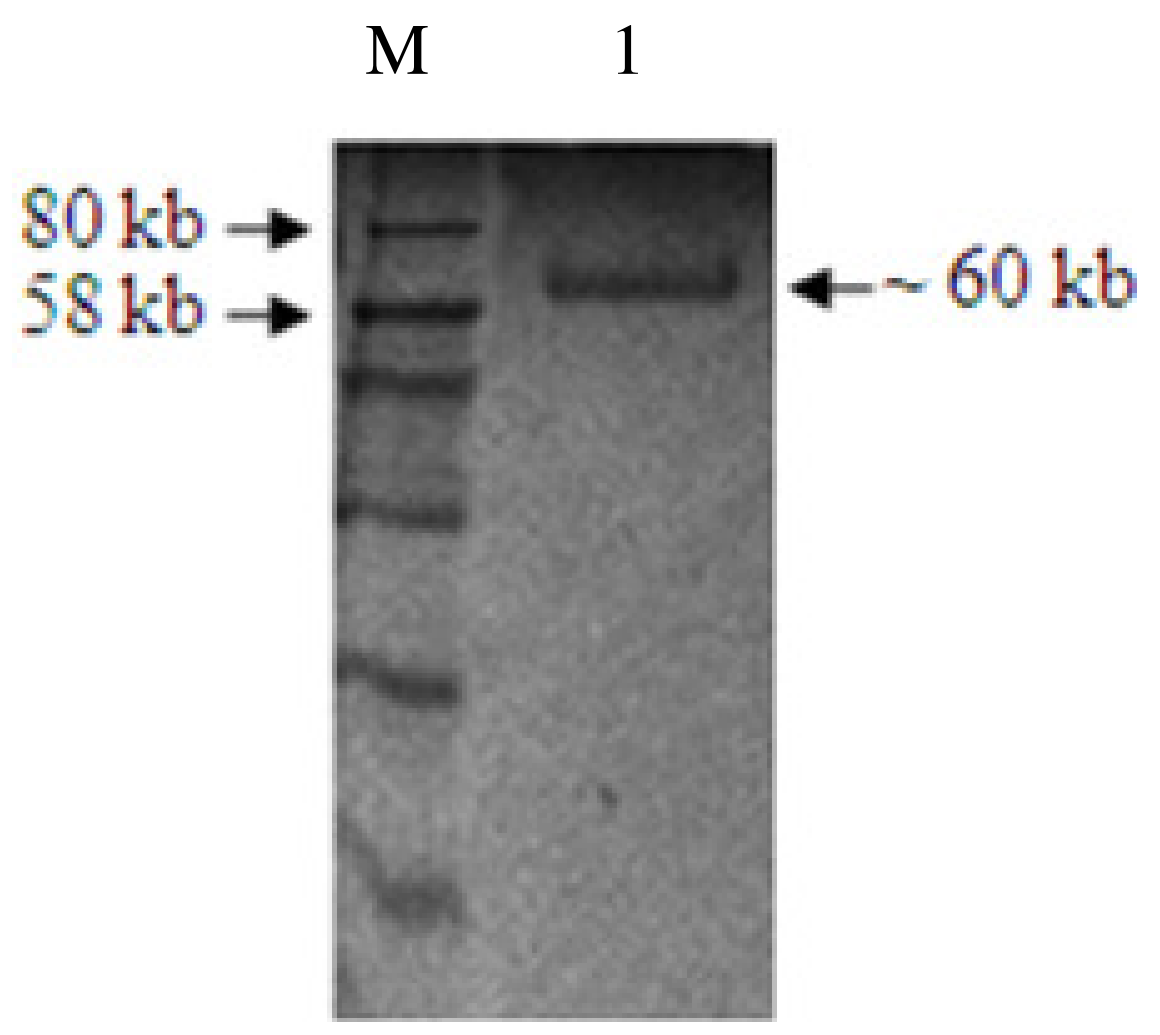

Figure 6. SDS-PAGE (12\%) profile of purified MAN1 recombinant proteins. 
Table 2. Summary of recombinant MAN1 purification.

\begin{tabular}{|c|c|c|c|c|c|c|c|c|}
\hline $\begin{array}{l}\text { Purification } \\
\text { step }\end{array}$ & $\begin{array}{l}\text { Volume } \\
\text { (ml) }\end{array}$ & $\begin{array}{c}\text { Amount of } \\
\text { protein } \\
(\mathrm{mg} / \mathrm{ml})\end{array}$ & $\begin{array}{l}\text { Amount of total } \\
\text { protein }(\mathrm{mg})\end{array}$ & $\begin{array}{l}\text { Activity } \\
\text { (U/ml) }\end{array}$ & $\begin{array}{c}\text { Total } \\
\text { Activity(U) }\end{array}$ & $\begin{array}{c}\text { Specific activity } \\
(\mathrm{U} / \mathrm{mg})\end{array}$ & $\begin{array}{l}\text { Purification } \\
\text { factor(Fold) }\end{array}$ & $\begin{array}{c}\text { Recovery } \\
\text { (\%) }\end{array}$ \\
\hline $\begin{array}{l}\text { Crude } \\
\text { supernatant }\end{array}$ & 1000 & 0.20 & 201.6 & 54.58 & 54579.44 & 270.73 & 1 & 100 \\
\hline Ultra filtration & 20 & 6.30 & 126.08 & 2063.26 & 41265.28 & 327.29 & 1.21 & 75.61 \\
\hline IMAC & 0.9 & 21.82 & 19.64 & 30896.35 & 27806.71 & 1416.18 & 5.23 & 50.95 \\
\hline
\end{tabular}

(a)

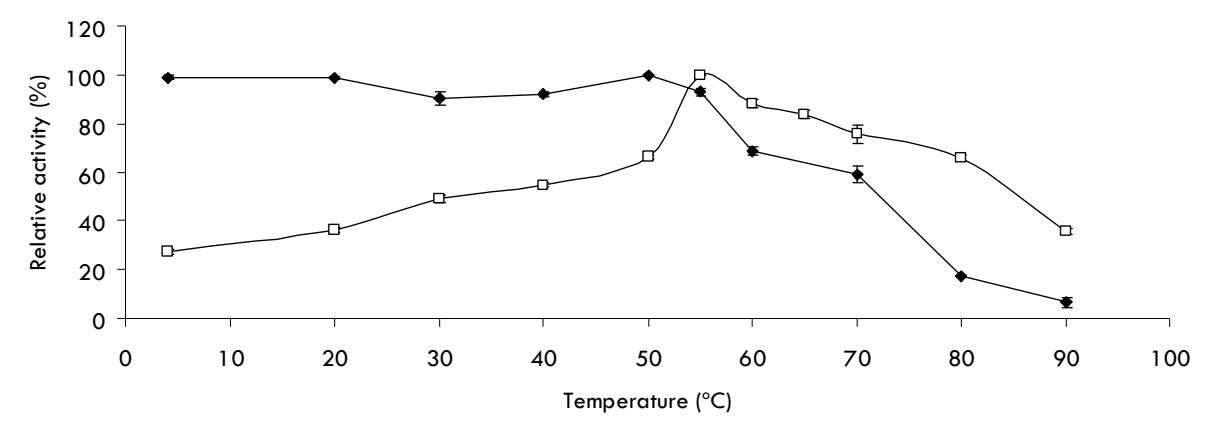

(b)

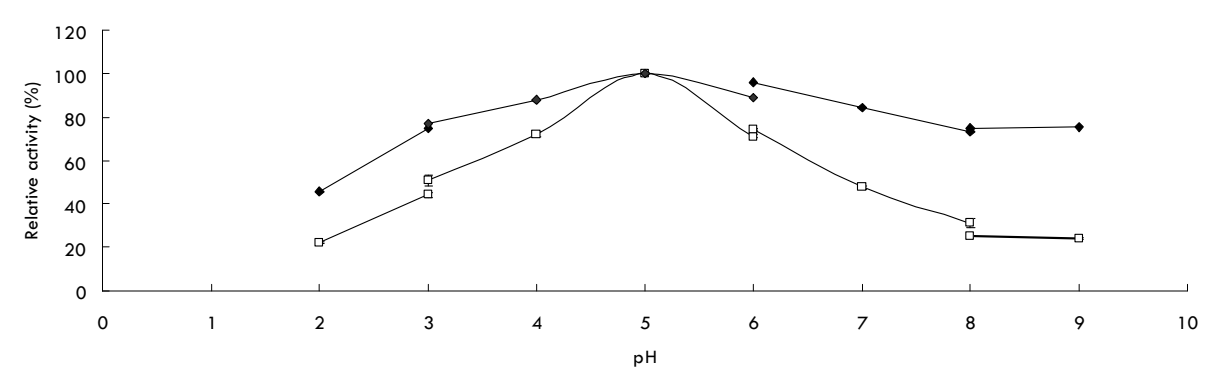

Figure 7. Biochemical characterization of $T$. Iongibrachiatum rMAN1. (a) Effect of temperature (口) and thermal stability $(\diamond)$ of the purified rMAN1. (b) Effect of pH ( $\square$ ) and pH stability $(\bullet)$ of the purified rMAN1. 


\section{Purification of recombinant MAN1}

The purification steps for MAN1 are summarized in Table 2. High level expression of recombinant protein in $P$. pastoris X-33 was obtained. From the shake flask cultivation, $201.6 \mathrm{mg} / \mathrm{L}$ of protein was obtained for X$33 / M A N 1$. The production of rMAN1 in this experiment was higher than that of Mytilus edulis $\beta$-mannanase expressed in $P$. pastoris (100 mg/L) (Xu et al., 2002) and $A$. aculeatus $\beta$-mannanase in $S$. cerevisiae (86 to 150 $\mathrm{mg} / \mathrm{L}$ ) (Setati et al., 2001). However, the amount of $\beta$ mannanase produced here was lower than that of Chen et al. (2006), who showed a production level of $262 \mathrm{mg} / \mathrm{L}$ $A$. sulphureus $\beta$-mannanase in $P$. pastoris. The purification steps presented yielded an enzyme preparation that appeared to be homogeneous and pure, as observed by a Coomassie-stained single band detected for rMAN1 in SDS-PAGE (Figure 6). The molecular mass of mature MAN1 deduced from the amino acid sequence was $\sim 49 \mathrm{kDa}$; however, the expressed rMAN1 from $P$. pastoris X-33 transformant was $\sim 60 \mathrm{kDa}$. The higher molecular mass of rMAN1 might be ascribed to glycosylation as four glycosylation sites were predicted in the deduced amino acid sequence.

\section{Biochemical characterization of rMAN1}

\section{Effect of temperature and $\mathrm{pH}$}

rMAN1 was active between 4 and $90^{\circ} \mathrm{C}$, with an optimum activity at $55^{\circ} \mathrm{C}$ (Figure 7 ). The optimum temperature for $T$. longibrachiatum $\beta$-mannanase activity was similar to the $\beta$-mannanases of other mesophilic microorganisms such as $A$. sulphureus (Chen et al., 2006), Aspergillus fumigatus IMI 385708 (Puchart et al., 2004), Bacillus licheniformis THCM 3.1 (Kanjanavas et al., 2009) and Trichoderma harzianum T4 (Ferreira and Filho, 2004), which were in the range of 45 to $55^{\circ} \mathrm{C}$ (Table 3). However, the optimum temperature was lower when compared to $\beta$-mannanases of thermophiles, T. neapolitana 5068, displayed an optimum activity at $90^{\circ} \mathrm{C}$ (Table 3 ). Temperatures above $80^{\circ} \mathrm{C}$ resulted in the rapid inactivation of rMAN1, defining an upper limit to its thermotolerance. It is noted that the enzyme was stable up to $55^{\circ} \mathrm{C}$, with a half-life of $30 \mathrm{~min}$ at $70^{\circ} \mathrm{C}$ (Figure 7a). This result showed that MAN1 is more thermostable than $M$. edulis $\beta$-mannanase, which loses its activity within 1 min at $60^{\circ} \mathrm{C}$, and Clostridium tertium $\mathrm{KT}-5 \mathrm{~A}$, which only retains stability up to $45^{\circ} \mathrm{C}$ for $10 \mathrm{~min}$ (Table 3 ).

Purified rMAN1 exhibited enzymatic activity over a $\mathrm{pH}$ range of 2 to 9 with an optimal $\mathrm{pH}$ at 5 (Figure $7 \mathrm{~b}$ ). The optimum $\mathrm{pH}$ for rMAN1 was similar to those of fungal $\beta$ mannanases that usually lie between 3.0 and 5.5 (Table
3). However, it is lower than those of bacterial $\beta$ mannanases, which have an optimum $\mathrm{pH}$ close to neutral (Table 3 ). The relative activity of the recombinant MAN1 was less than $50 \%$ at $\mathrm{pH}$ levels lower than $\mathrm{pH} 3$ and higher than $\mathrm{pH} 6$. The enzyme was stable at $55^{\circ} \mathrm{C}$ for 30 min from $\mathrm{pH} 4$ to 7 but became progressively unstable at $\mathrm{pH}$ values below 3 (Figure $7 \mathrm{~b}$ ).

\section{Determination of kinetic parameters}

When LBG, guar gum and CMC were used as the substrates, larger quantities of reducing sugars were liberated during the hydrolysis of LBG. A decline in reducing sugars of $\sim 75 \%$ was observed when guar gum was used. However, no detectable reducing sugars were released during incubation with 1\% CMC. These results indicate that the hydrolytic ability of rMAN1 depended on the nature of the substitution sugar in the mannan backbone; it could not hydrolyze the $\beta-1$, 4-cellulosidic linkages of CMC but could only hydrolyze the $\beta-1,4-$ mannosidic linkages of mannan.

The $\mathrm{K}_{\mathrm{m}}$ and $\mathrm{V}_{\max }$ values were determined directly from Lineweaver-Burk double reciprocal plots. From the analysis, MAN1 had lower $K_{\mathrm{m}}$ in LBG $(0.95 \mathrm{mg} / \mathrm{ml})$ as compared to guar gum $(2.65 \mathrm{mg} / \mathrm{ml})$. Therefore, MAN1 exhibited low specificity with guar gum (mannose/galactose ratio, 2:1) but high specificity with LBG (mannose/galactose ratio, 4:1). This result indicated that the hydrolysis yield depended on the degree of galactose present as the side chain. MAN1 was found to exhibit decreased specificity with an increase in galactose substitution in galactomannans. It has been suggested that $T$. reesei $\beta$-mannanase contains at least four substrate binding subsites (Harjunpää et al., 1995). Therefore, binding to at least four subsites is required for efficient hydrolysis. Substitution of the substrate monomers at one of the subsite positions restricted hydrolysis, likely by inhibiting binding (McCleary, 1988). The $K_{m}$ value of MAN1 for LBG was considerably lower than $\beta$-mannanases from $T$. harzianum T4, A. fumigatus IMI 385708, B. stearothermophilus, P. occitanis Pol6 and M. edulis, indicating higher substrate specificity (Table 3 ). Furthermore, rMAN1 exhibited higher catalytic efficiency towards LBG, and the $\mathrm{k}_{\mathrm{cat}} / \mathrm{K}_{\mathrm{m}}$ was 2.39-fold higher than the catalytic efficiency towards guar gum.

\section{Conclusion}

A fungus producing $\beta$-mannanase was identified as $T$. longibrachiatum, and its $\beta$-mannanase encoding gene was isolated. The recombinant MAN1 was successfully expressed and validated by western blotting. The consi- 
Table 3. Comparison of characteristics of $T$. longibrachiatum MAN1 and other $\beta$-mannanases.

\begin{tabular}{|c|c|c|c|c|c|c|c|c|}
\hline \multirow[b]{2}{*}{ Organism } & \multirow[b]{2}{*}{ Enzyme } & \multirow[b]{2}{*}{$\underset{(\mathrm{kDa})}{\mathrm{M}_{\mathrm{w}}}$} & \multicolumn{2}{|c|}{ Optimum } & \multicolumn{2}{|c|}{ Stability } & \multirow[b]{2}{*}{ Substrate } & \multirow[b]{2}{*}{$\mathrm{K}_{\mathrm{m}}(\mathrm{mg} / \mathrm{ml})$} \\
\hline & & & $\mathrm{pH}$ & $\begin{array}{c}\text { Temperature } \\
\left({ }^{\circ} \mathrm{C}\right)\end{array}$ & $\mathrm{pH}$ & Temperature $\left({ }^{\circ} \mathrm{C}\right)$ & & \\
\hline T. longibrachiatum (Current study) & MAN1 & 60 & 5 & 55 & $4-6$ (30 min) & $55(30 \mathrm{~min})$ & LBG & 0.95 \\
\hline A. sulphureus ${ }^{c}$ (Chen et al., 2006) & MANN & 48 & 2.4 & 50 & 2.4-3.4 (1 h) & $40(6 \mathrm{~h})$ & LBG & 0.93 \\
\hline \multirow{2}{*}{$\begin{array}{l}\text { A. fumigatus IMI } 385708 \text { (Puchart } \\
\text { et al., 2004) }\end{array}$} & MAN I & 60 & 4.5 & 65 & 4-8.5 (5 h) & $55(6 \mathrm{~h})$ & LBG & 3.07 \\
\hline & MAN II & 63 & 4.5 & 65 & $4.5-9(5 \mathrm{~h})$ & $55(6 \mathrm{~h})$ & LBG & 3.12 \\
\hline $\begin{array}{l}\text { B. licheniformis THCM } 3.1^{\text {a }} \\
\text { (Kanjanavas et al., 2009) }\end{array}$ & ManBL3.1 & 40 & 9 & 45 & 7-9 (48 h) & $45(48 \mathrm{~h})$ & LBG & 2.52 \\
\hline $\begin{array}{l}\text { B. stearothermophilus }{ }^{\mathrm{a}} \text { (Ethier et } \\
\text { al., 1998) }\end{array}$ & ManF & 73 & 6.5 & 70 & $N D^{g}$ & $N D^{g}$ & LBG & 2.4 \\
\hline $\begin{array}{l}\text { C. tertium KT-5A (Kataoka and } \\
\text { Takiwa, 1998) }\end{array}$ & $\beta$-mannanase & $N D^{h}$ & 6.5 & 55 & 6-7 (3.5 h) & 45 (10 min) & $\begin{array}{l}\text { LBG, Spino gum, Guar } \\
\text { gum, } \\
\text { Konjac flour,Waxy starch, } \\
\text { CMC }^{\text {i }}\end{array}$ & $N D^{h}$ \\
\hline \multirow{2}{*}{ M. edulis ( Xu et al., 2002) } & ManA & 39 & 5.2 & 50 & $4-9.5(24 \mathrm{~h})$ & $40\left(N^{g}\right)$ & LBG & 3.95 \\
\hline & ManB & 39 & 5.2 & 50 & $4-9.5(24 \mathrm{~h})$ & $40\left(N D^{9}\right)$ & LBG & $N D^{g}$ \\
\hline $\begin{array}{l}\text { Penicillium occitanis Pol6 (Blibech } \\
\text { et al., 2010) }\end{array}$ & Manlll & 18 & 4 & 40 & $2-12(24 h)$ & 70 (30 min) & LBG & 17.94 \\
\hline $\begin{array}{l}\text { Thermotoga neapolitana } 5068 \\
\text { (Duffaud et al., 1997) }\end{array}$ & $\beta$-mannanase & 65 & 7 & 90 & $N D^{g}$ & $N D^{g}$ & $\begin{array}{l}\text { LBG } \\
\text { Azo-carob galactomannan }\end{array}$ & $\begin{array}{l}0.55 \\
0.23\end{array}$ \\
\hline $\begin{array}{l}\text { T. harzanum T4 (Ferreira and Filho, } \\
\text { 2004) }\end{array}$ & Man I & 32.5 & 3 & 55 & $7.5-8\left(N^{g}\right)$ & $50\left(N D^{g}\right)$ & LBG & 1.3 \\
\hline \multirow{2}{*}{$\begin{array}{l}\text { T. reesei RutC30 (Stålbrand et al., } \\
\text { 1995) }\end{array}$} & Man1 Pi 4.6 & 51 & 5.3 & 70 & 4-7 (24 h) & 80 (30 min) & LBG & \multirow{2}{*}{$N D^{g}$} \\
\hline & Man1 Pi 5.4 & 53 & 5.3 & 70 & $3.5-6(24 \mathrm{~h})$ & 80 (30 min) & LBG & \\
\hline
\end{tabular}

${ }^{a}$ Expressed in E. coli, ${ }^{b}$ Expressed in S. cerevisiae, ${ }^{\mathrm{C}}$ Expressed in P. pastoris, ${ }^{\mathrm{d}} \mathrm{N}$-bromosuccinimide, ${ }^{\mathrm{e}} 5,5$-dithio-bis(2-nitrobenzoic acid), ${ }^{\mathrm{f} D}$ Dithiothreitol, ${ }^{9} \mathrm{Not}$ determined..${ }^{\mathrm{h}} \mathrm{Dimethyl}$ sulfoxide $\mathrm{Carboxymethyl} \mathrm{cellulose}$ 
derable high specific activity (1416 U/mg) and high level of expression in shake flask cultivation $(0.2 \mathrm{mg} / \mathrm{ml})$ made rMAN1 potentially cost-effective. Moreover,subsequent research can be focused on how to increase the recombinant protein yield using a bioreactor.

\section{ACKNOWLEDGMENT}

The authors would like to acknowledge financial support from the National Biotechnology Division, Ministry of Science Technology and Innovation (MOSTI), Malaysia, through grant no. 02-06-14-SF001 and 07-05-MGIGMB012.

\section{REFERENCES}

Aehle W (2007). Enzymes in industry, 3rd Edn. Wiley-VCH Verlag $\mathrm{GmbH}$ and $\mathrm{Co}$, Weinheim.

Al-Rashed SAA, Bakar FDA, Said M, Hassan O, Rabu A, Illias RM, Murad AMA (2010). Expression and characterization of the recombinantTrichoderma virens endochitinase Cht2. Afr. J. Microbiol. Res. 4(16): 1758-1767.

Altschul SF, Madden TL, Schaffer AA, Zhang J, Zhang Z, Miller W, Lipman DJ (1997). Gapped BLAST and PSI-BLAST: a new generation of protein database search programs. Nucleic Acids Res. 25(17): 3389-3402.

Bendtsen JD, Nielsen H, Von Heijne G, Brunak S (2004). Improved prediction of signal peptides: SignalP 3.0. J. Mol. Biol. 340(4): 783795.

Bo X, Lei D, Tang XH, Li JJ, Mu YL, Yang YJ, Zunxi H (2009). Characterization of 6 Bacillus subtilis $\beta$-mannanases and their genes. Afr. J. Biotechnol. 8 (18): 4316-4324

Blibech M, Ghorbel RE, Fakhfakh I, Ntarima P, Piens K, Bacha AB, Chaabouni SE (2010). Purification and characterisation of a low molecular weight of $\beta$-mannanase from Penicillium occitanis Pol6. Appl. Biochem. Biotechnol. 160(4): 1227-1240.

Breathnach R, Chambon P (1981). Organization and expression of eukaryotic split genes coding for proteins. Annu. Rev. Biochem. 50: 349-383.

Cereghino GPL, Cereghino JL, Ilgen C, Cregg JM (2002). Review: Production of recombinant proteins in fermenter cultures of the yeast Pichia pastoris. Curr. Opin. Biotechnol. 13(4): 329-332.

Chen XL, Cao YH, Ding YH, Lu WQ, Li DF (2006). Cloning, functional expression and characterisation of Aspergillus sulphureus $\beta$ mannanase in Pichia pastoris. J. Biotechnol. 128(3): 452-461.

Druzhinina IS, Kopchinskiy AG, Komoń M, Bissett J, Szakacs G, Kubicek CP (2005). An oligonucleotide barcode for species identification in Trichoderma and Hypocrea. Fungal Genet. Biol. 42(10): 813-828.

Duffaud GD, McCutchen CM, Leduc P, Parker KN, Kelly RM (1997). Purification and characterisation of extremely thermostable $\beta$ mannanase, $\beta$-mannosidase, and $\alpha$-galactosidase from the hyperthermophilic eubacterium Thermotoga neapolitana 5068. Appl. Environ. Microbiol. 63(1): 169-177.

Ethier N, Talbot G, Sygusch J (1998). Gene cloning, DNA sequencing, and expression of thermostable $\beta$-mannanase from Bacillus stearothermophilus. Appl. Environ. Microbiol. 64(11): 4428-4432.

Ferreira HM, Filho EXF (2004). Purification and characterisation of a $\beta$ mannanase from Trichoderma harzianum strain T4. Carbohydr. Polym. 57(1): 23-29.

Finn RD, Tate J, Mistry J, Coggil PC, Sammut JS, Hotz HR, Ceric G,
Forslund K, Eddy SR, Sonnhammer EL, Bateman A (2008). The Pfam protein families database. Nucleic Acids Res. 36: D281-D288.

Harjunpää V, Teleman A, Siika-aho M, Drakenberg T (1995). Kinetic and stereochemical studies of manno-oligosaccharide hydrolysis catalysed by $\beta$-mannanases from Trichoderma reesei. Eur. J. Biochem. 234(1): 278-283.

Käll L, Krogh A, Sonnhammer EL (2004). A combined transmembrane topology and signal peptide prediction method. J. Mol. Biol. 338(5): 1027-1036.

Kanjanavas P, Khawsak P, Pakpitcharoen A, Areekit S, Sriyaphai T, Pothivejkul K, Santiwatanakul S, Matsui K, Kajiwara T, Chansiri K (2009). Over-expression and characterisation of the alkalophilic, organic solvent-tolerant, and thermotolerant endo-1, 4- $\beta$-mannanase from Bacillus licheniformis isolate THCM 3.1. Science Asia, 35(1): 14 23.

Kataoka N, Tokiwa $Y$ (1998). Isolation and characterisation of an active mannanase-producing anaerobic bacterium, Clostridium tertium KT5A, from lotus soil. J. Appl. Microbiol. 84(3): 357-367.

Laemmli UK (1970). Cleavage of structural proteins during the assembly of the heat of bacteriophage T4. Nature, 227: 680-685.

Larkin MA, Blackshields G, Brown NP, Chenna R, McGettigan PA, McWilliam H, Valentin F, Wallace IM, Wilm A, Lopez R, Thompson JD, Gibson TJ, Higgins DG (2007). Clustal W and Clustal X version 2.0. Bioinformatics, 23(21): 2947-2948.

Mudau MM, Setati ME (2008). Partial purification and characterization of endo- $\beta-1,4-m a n n a n a s e s$ from Scopulariopsis candida strains isolated from solar salterns. Afr. J. Biotechnol. 7 (13): 2279-2285.

Marraccini P, Rogers WJ, Allard C, Andre ML, Caillet V, Lacoste N, Lausanne $F$, Michaux $S$ (2001). Molecular and biochemical characterisation of endo- $\beta$-mannanases from germinating coffee (Coffea arabica) grains. Planta, 213(2): 296-308.

McCleary BV (1988). $\beta$-D-mannanase. Meth Enzymol. 160: 596-610.

Mehri M, Adibmoradi M, Samie A, Shivazad M (2010). Effects of $\beta$ mannanase on broiler performance, gut morphology and immune system. Afr. J. Biotechnol. 9(37): 6221-6228

Miller GL (1959). Use of dinitrosalicylic acid reagent for determination of reducing sugars. Analy. Chem. 31(3): 426-428.

Montiel MD, Rodriguez J, Pérez-Leblic MI, Hernández M, Arias ME., Copa-Patiño JL (1999). Screening of mannanases in actinomycetes and their potential application in the bleaching of pine kraft pulps. Appl. Microbiol. Biotechnol. 52: 240-245.

Oh SSL, Bakar FDA, Adnan AM, Mahadi NM, Hassan O, Murad AMA (2009). Isolation and characterization of glyceraldehydes-3phosphate dehydrogenase gene of Trichoderma virens UKM1. Biotechnology, 8: 194-203.

Petkowicz CLO, Reicher F, Chanzy H, Taravel FR, Vuong R (2001). Linear mannan in the endosperm of Schizolobium amazonicum. Carbohydr. Polymer. 44(2): 107-112.

Puchart V, Vršanská M, Svoboda P, Pohl J, Ögel ZB, Biely P (2004). Purification and characterisation of two forms of endo- $\beta-1,4$ mannanase from a thermotolerant fungus, Aspergillus fumigates IMI 385708 (formerly Thermomyces lanuginosus IMI 158749). Biochim. Biophys. Acta. 1674(3): 239-250.

Reese MG (2001). Application of a time-delay neural network to promoter annotation in the Drosophila melanogaster genome. Comput. Chem. 26(1): 51-56.

Sabini E, Schubert H, Murshudov G, Wilson KS, Siika-Aho M, Penttilä $M(2000)$. The three-dimensional structure of a Trichoderma reesei $\beta$ mannanase from glycoside hydrolase family 5. Acta Crystallogr. D 56(1): 3-13.

Sachslehner A, Foidl G, Foidl N, Gübitz G, Haltrich D (2000). Hydrolysis of isolated coffee mannan and coffee extract by mannanases of Sclerotium rolfsii. J. Biotechnol. 80(2): 127-134.

Samuels GJ (2006). Trichoderma: Systematics, the sexual state, and ecology. Phytopathology, 96(2): 195-206.

Schwartz TW (1986). The processing of peptide precursors, "prolinedirected arginyl cleavage' and other monobasic processing 
mechanisms. FEBS Lett. 200(1): 1-10.

Setati ME, Ademark $\mathrm{P}$, van Zyl WH, Hahn-Hagerdal B, Stålbrand $\mathrm{H}$ (2001). Expression of the Aspergillus aculeatus endo- $\beta-1$, 4mannanase encoding gene (man1) in Saccharomyces cerevisiae and characterisation of the recombinant enzyme. Protein Expression Purif. 21(1): 105-114.

Stålbrand $\mathrm{H}$, Saloheimo A, Vehmaanperä J, Henrissat B, Penttila M (1995). Cloning and expression in Saccharomyces cerevisiae of a Trichoderma reesei $\beta$-mannanase gene containing a cellulose binding domain. Appl. Environ. Microbiol. 61(3): 1090-1097.

White TM, Bruns T, Lee S, Taylor J (1990). Amplification and direct sequencing of fungal ribosomal RNA for phylogenetics. Academic Press, San Diego.
Xu B, Sellos D, Janson JC (2002). Cloning and expression in Pichia pastoris of a blue mussel (Mytilus edulis) $\beta$-mannanase gene. Eur. J. Biochem. 269(6): 1753-1760.

Zhang Y, Liu R, Wu X (2007). The proteolytic systems and heterologous proteins degradation in the methylotrophic yeast Pichia pastoris. Ann. Microbiol. 57(4): 553-560. 